\title{
ALUMINUM AND ZINC OXIDES NANOPARTICLES AS A NEW METHODS FOR CONTROLLING THE RED FLOUR BEETLES, Tribolium castaneum (HERBEST) COMPARED TO MALATHION INSECTICIDE. \\ Abeer A.Salem; Amal, M.Hamzah and Nariman,M.El-Taweelah. Plant production research Institute ,Sakha, Kafr El-Sheikh, Egypt.
}

\begin{abstract}
Among the red flour beetles, Tribolium castaneum (Herbest) is a cosmopolitan and serious pest of cereal grains and their products. Undoubtedly, the excessive use of pesticides and chemical compounds led to a lot of diseases to humans, animals and the environment, in addition to high costs. In the present study two nanoparticles, Aluminum oxide $\left(\mathrm{Al}_{2} \mathrm{O}_{3}\right)$ and $\mathrm{Zinc}$ oxide $(\mathrm{ZnO})$ were used as stored product insect protectants compared to malathion as standard reference. Results obtained cleared showed that malathion had the highest adverse effect on the all parameters studied of $T$. castaneum adults viz, mortality, offspring and weight loss percentage. Data obtained indicated that the increasing of concentration and exposure period caused increasing in mortality (\%) and decreasing in weight loss (\%).Also results accentuated that the two nanoparticles $\left(\mathrm{Al}_{2} \mathrm{O}_{3}\right.$ and $\left.\mathrm{ZnO}\right)$ significantly inhibited the number of progeny and weight loss (\%) and the concentration of $2 \mathrm{~g} / \mathrm{kg}$ wheat grain had the highest effect based on the $\mathrm{LC}_{50}$ values $\mathrm{ZnO}$ was had the most effect compared to $\mathrm{Al}_{2} \mathrm{O}_{3}$ nanoparticles.

Finally, although malation was the premier, the present study suggest to use $\mathrm{Al}_{2} \mathrm{O}_{3}$ and $\mathrm{ZnO}$ nanoparticles in integrated pest management programs as alternative to chemical insecticides where they are considered safe for humans if compared with synthetic insecticide.
\end{abstract}

\section{INTRODUCTION}

Post-harvesting grain crops are exposed to many insect pests that cause loss in quantity in addition to low quality. Among the red flour beetles, Tribolium castaneum (Herbst) is a cosmopolitan and serious pest of cereal grains and their products. Adult beetle and larva feed on stored food stuffs viz. dry fruits, pulses, bran, coat, germ, grain dust and prepared cereal foods. (Atwal, 1976; Hamed and Khattak, 1985; Khattak et al., 1999; Dars et al., 2001). This insect is unable to feed on intact grains, however, it does considerable loss to grains damaged by other insects and flour and other products ( $\mathrm{Li}$ and Arbogast, 1991). In case of serious infestation, the flour turns yellowish and mouldy, has a pungent, disagreeable odour and becomes unfit for human consumption (Atwal, 1976).

This loss in weight and quality could be prevented either by use of pesticides or by non-chemical methods. Chemical methods involve the use of synthetic insecticides in most parts of the world.

Reacting to the disadvantages of using traditional chemical pesticides was the need to use modern methods of combat such as nanotechnology.

Nanotechnology, the process to generate, manipulate, and deploy nanomaterials, represents an area holding significant promise for the 
agricultural scenario (Baruah and Dutta, 2009; Navrotsky, 2000; Kuzma, 2007). Nanotechnology employs nanoparticles (NPs) having one or more dimensions in the order of $100 \mathrm{~nm}$ or less (Auffan et al., 2009). Other authors refer to NPs as colloidal particulate systems with size ranging between 10 and $1000 \mathrm{~nm}$. Nanomaterials hold great promise regarding their application in plant protection and nutrition due to their size-dependent qualities, high surface-to-volume ratio and unique optical properties. A wide variety of materials are used to make NPs, such as metal oxides, ceramics, silicates, magnetic materials, semiconductor quantum dots (QDs),lipids, polymers, dendrimers and emulsions (Niemeyer and Doz, 2001; Oskam, 2006; Puoci et al., 2008).

The aim of this study was to investigate the entomotoxicity of Aluminum oxide (Al2O3) and Zinc Oxide $(\mathrm{ZnO})$ nanoparticles compared to malathion against $T$. castaneum (Herbest) under laboratory conditions.

\section{MATERIALS AND METHODS}

\section{Synthesis of Aluminum oxide $\left(\mathrm{Al}_{2} \mathrm{O}_{3}\right)$ nanoparticles}

Chemical routes for production of these materials Include sol-gel, hydrothermal processing and control precipitation of boehmite obtained from aluminum salts, alkoxides and metallic Powders. Gamma alumina nanoparticles was prepared by sol gel method using aluminium nitrate precursor and ammonium carbonate route possess spherical nano-sized particle (Ruihong et al., 2006 and Hochepied et al., 2003). User-sized experiments were $10 \pm 2 \mathrm{~nm}$.

\section{Synthesis of Zinc Oxide ( $\mathrm{ZnO})$ nanoparticles}

$\mathrm{ZnO}$ nanoparticles has been prepared as reported by ( Beek et al.,2005) through the hydrolysis and condensation of zinc acetate dehydrate by potassium hydroxide in alcoholic medium at low temperature condition. The $\mathrm{ZnO}$ nanoparticles settled at the bottom and the excess mother liquor was removed and the precipitate was washed with methanol. The precipitate was then dispersed in a mixture of methanol and of chloroform (Seow et al., 2009). User-sized experiments were $20 \pm 5 \mathrm{~nm}$.

Both compounds were prepared in Nanotech Egypt Company Limited, Cairo, Egypt.( pure 99.99\%) and their use in the form of powders concentration $2,1,0.5,0.25$ and $0.125 \mathrm{~g} / \mathrm{Kg}$ crush.

\section{Chemical insecticide:}

\section{Malathion}

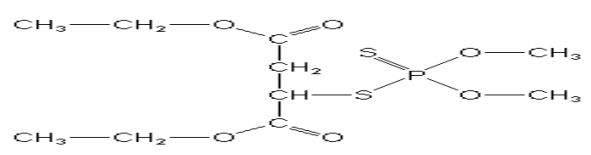

Common name: Malathion

Chemical name: 0,0 dimethyl-S-(1,2 dicarboxyethyl)

Ethylophosporodithioate

Formula: $\mathrm{C}_{10} \mathrm{H}_{19} \mathrm{O}_{6} \mathrm{PS}_{2}$ 
Dust (1\%) concentration $0.1,0.08,0.06$ and $0.04 \mathrm{~g} / \mathrm{Kg}$ to compared with both nanoparticles .

Multiplication of Tribolium castaneum for the experiment:

The insect's culture was established to supply adequate number of the insects of similar age for the experiments. Sufficient quantities of crushed grains were firstly sieved to remove stone, dust and insects. The crushed grains were then sterilized by freezing for $24: 48 \mathrm{~h}$ at -18 to $22^{\circ} \mathrm{C}$. All crushed grains were maintained in an incubator at a constant temperature of $29 \pm 1$ ${ }^{\circ} \mathrm{C}$ and $65 \pm 5 \%$ R.H. for two weeks to obtain equilibration moisture content with this R.H. (Ezz, 1976). Newly emerged of Tribolium castaneum adults were introduced into buckets containing the disinfested crushed wheat. Ten days after introduction, adults were removed from each bucket and the containers were observed beginning from 30 days after the insect's introduction for emergence of offspring.

\section{Lethality effect:}

Different concentrations of nanoparticles and malathion were admixed with crushed grains to determine their effects. Concentrations of 2,1, $0.5,0.25$ and $0.125 \mathrm{gm}$. $/ \mathrm{kg}$. for nanoparticles and $0.04,0.06,0.08$ and 0.1 $\mathrm{g} / \mathrm{kg}$ of malathion. Each of prepared concentration was added to twenty gm crushed grains infested with 20 newly emerged adults (1-2 weeks - old) of Tribolium castaneum. In jars $(250 \mathrm{ml})$ three replicates done for each treatment and the control. All replicates were kept at $27 \pm 1{ }^{\circ} \mathrm{C}$ and $65 \pm 5 \%$ R.H. for all treatments and the control.

\section{Effect on biology, damage and grain weight loss:}

The crushed grains were treated with the same concentrations used with the toxic effect method mentioned above. After 15 days of treatment the insects were removed, after 60 days of exposure the emerged insect adults were recorded and the percent of reduction, and grain weight loss were estimated.

\section{Data analysis:}

Analysis of variance (ANOVA) procedures in SAS (2008) were used to detect differences between treatment means.

\section{RESULTS AND DISCUSSION}

Looking into data obtained in Table (1) show that malathion significantly increased mortality and reduced the number of progeny and weight loss when the concentration increased compared to control. Mortality percentage ranged frm 41.7 to 98.3 after two weeks post treatment at the all tested concentrations of malathion, also the number of progeny reached to 5 , 32,72 and 95 at concentrations of $0.1,0.08,0.06$ and $0.04 \mathrm{~g} / \mathrm{kg}$. , respectively.

Moreover, the percent weight loss decreased from 6.9 to $2.1 \%$ at 0.04 and $0.1 \mathrm{~g} / \mathrm{kg}$, respectively. 
Table (1): Effect of malathion on mortality, emergency, reduction percentage and weight loss percentages of T.castaneum adults.

\begin{tabular}{|c|c|c|c|c|c|}
\hline \multirow{2}{*}{$\begin{array}{l}\text { Con. } \\
w / w\end{array}$} & \multicolumn{2}{|c|}{$\begin{array}{c}\% \text { Adult Mortality } \\
\text { after }\end{array}$} & \multirow{2}{*}{$\begin{array}{l}\text { Mean no. f } \\
\text { emerged } \\
\text { adults }\end{array}$} & \multirow{2}{*}{$\begin{array}{c}\% \text { Reduction } \\
\text { of adults }\end{array}$} & \multirow{2}{*}{$\begin{array}{l}\% \text { Weight } \\
\text { loss }\end{array}$} \\
\hline & 1 week & 2 weeks & & & \\
\hline 0.04 & 41.7 & 60.0 & 95 & $48.1 \mathrm{~d}$ & $6.9 \mathrm{~b}$ \\
\hline 0.06 & 53.3 & 73.3 & 72 & $63.1 \mathrm{c}$ & $4.7 \mathrm{c}$ \\
\hline 0.08 & 66.7 & 91.7 & 32 & $83.6 \mathrm{~b}$ & $3.3 \mathrm{~d}$ \\
\hline 0.1 & 81.7 & 98.3 & 5 & $97.4 \mathrm{a}$ & $2.1 \mathrm{e}$ \\
\hline Untreated & & & 195 & & 34 \\
\hline
\end{tabular}

Data illustrated in Table (2), indicated that accumulative mortality (\%) of $T$. castaneum increased gradually by increase the period of exposure and scored a higher mortality reached to $30.66 \pm 0.33$ and $68.66 \pm 0.88$ individuals after 6 and 15 days for treated with $\mathrm{Al}_{2} \mathrm{O}_{3}$ nanoparticles at concentration of 2 $\mathrm{gm} . / \mathrm{kg}$, respectively.

Also the results in Table (2) revealed that the reduction percentages of progeny was increased with the increased of concentration. The highly reduction was observed with concentration of $2 \mathrm{~g} / \mathrm{Kg}$ for Aluminum oxide $\left(\mathrm{Al}_{2} \mathrm{O}_{3}\right)$ nanoparticles $(69.06 \%)$ for T.castaneum. Quite the contrary, the increased of concentration reduced the of number of progeny and weight loss percentage, where recorded that lowest effect on progeny at concentration 2 $\mathrm{g} / \mathrm{Kg}(60.33)$ individual and also less in weight percentage $(4.9 \%)$ at similar concentration.

Table (2): Percent mortality (Mean $\pm \mathrm{SE}$ ) of T.castaneum adults treated with Aluminum oxide $\left(\mathrm{Al}_{2} \mathrm{O}_{3}\right)$ nanoparticles under store conditions.

\begin{tabular}{|c|c|c|c|c|c|}
\hline \multirow{2}{*}{$\begin{array}{c}\text { Con. } \\
\text { (gm./Kg) }\end{array}$} & \multicolumn{2}{|c|}{$\begin{array}{c}\text { Adult mortality \% } \\
\text { after }\end{array}$} & $\begin{array}{c}\text { No. of emerged } \\
\text { after 60 days }\end{array}$ & $\begin{array}{c}\text { \% } \\
\text { Reduction }\end{array}$ & $\begin{array}{c}\text { \% Weight } \\
\text { loss }\end{array}$ \\
\hline 0.125 & $7.66 \pm 0.33$ & $19.33 \pm 0.33$ & $100.34 \pm 0.33$ & 48.54 & 10.4 \\
\hline 0.25 & $10.66 \pm 0.3327 .66 \pm 0.33$ & $93.66 \pm 0.88$ & 54.97 & 9.3 \\
\hline 0.5 & $18.33 \pm 0.3340 .33 \pm 0.33$ & $89.33 \pm 0.33$ & 54.19 & 8.7 \\
\hline 1 & $21.33 \pm 0.8851 .33 \pm 0.33$ & $81.66 \pm 0.88$ & 58.12 & 7.2 \\
\hline 2 & $30.66 \pm 0.3368 .66 \pm 0.88$ & $60.33 \pm 0.33$ & 69.06 & 4.9 \\
\hline
\end{tabular}

Data illustrated in Table (3), cleared that accumulative mortality (\%) of $T$. castaneum increased gradually by increased the period of exposure and the number of mortality scored a higher mortality reached to $34.66 \pm 0.33$ and $69.66 \pm 0.33$ individuals after 6 and 15 days for treated with $\mathrm{ZnO}$ nanoparticles at concentration of $2 \mathrm{gm} . / \mathrm{kg}$, respectively.

From Tables (2 and 3) clear to $\mathrm{ZnO}$ was more influential than $\mathrm{SiO}_{2}$ at the all concentrations exposed periods. 
Table (3): Percent mortality (Mean \pm SE) of T.castaneum adults treated with Zinc Oxide (ZnO) nanoparticles under store conditions.

\begin{tabular}{|c|c|c|c|c|c|}
\hline $\begin{array}{c}\text { Con. } \\
\text { (gm./Kg) }\end{array}$ & \multicolumn{2}{|c|}{$\begin{array}{c}\text { Adult mortality \% } \\
\text { after }\end{array}$} & $\begin{array}{c}\text { No. of emerged } \\
\text { after 60 days }\end{array}$ & $\begin{array}{c}\text { \% } \\
\text { Reduction }\end{array}$ & $\begin{array}{c}\text { \% Weight } \\
\text { loss }\end{array}$ \\
\cline { 2 - 5 } & $\mathbf{6}$ days & $\mathbf{1 5}$ days & & & \\
\hline 0.125 & $9.66 \pm 0.33$ & $20.33 \pm 0.33$ & $90.33 \pm 0.33$ & 53.67 & 8.9 \\
\hline 0.25 & $12.66 \pm 1.45$ & $29.33 \pm 0.66$ & $81.33 \pm 0.88$ & 58.29 & 7.3 \\
\hline 0.5 & $20.33 \pm 0.3342 .33 \pm 1.21$ & $69.00 \pm 0.33$ & 64.51 & 6.5 \\
\hline 1 & $26.00 \pm 1.01$ & $55.33 \pm 0.33$ & $59.66 \pm 0.33$ & 69.41 & 4.8 \\
\hline 2 & $34.66 \pm 0.3369 .66 \pm 0.33$ & $49.33 \pm 0.33$ & 74.70 & 4.3 \\
\hline
\end{tabular}

Also the results in Table (3) revealed that the reduction percentages of progeny were increased with the increase of concentration. The highly reduction was illustrated with concentration of $2 \mathrm{~g} / \mathrm{Kg}$ for Zinc Oxide $(\mathrm{ZnO})$ nanoparticles $(74.70 \%)$. Yet, the increased concentration reduced the weight loss percentage from 8.9 at $0.125 \mathrm{~g} / \mathrm{kg}$ to $4.3 \%$ at $2 \mathrm{~g} / \mathrm{kg}$ crushed wheat.

The LC50 values for $\mathrm{Al}_{2} \mathrm{O}_{3}$ and $\mathrm{ZnO}$ nanoparticles on adults of T.castaneum are shown in Table 4. According to these values, adults of T.castaneum were more sensitive to $\mathrm{ZnO}$ than $\mathrm{Al}_{2} \mathrm{O}_{3}$ nanoparticles. However, there was not any significant difference between LC50 of $\mathrm{ZnO}$ and $\mathrm{Al}_{2} \mathrm{O}_{3}$ nanoparticles. These results indicated that LC50 decreased with increasing in exposure periods.

Table (4): $\mathrm{LC}_{50}(\mathrm{~g} / \mathrm{Kg}$ Seed weight) values of with Aluminum oxide $\left(\mathrm{Al}_{2} \mathrm{O}_{3}\right)$ and Zinc Oxide ( $\left.\mathrm{ZnO}\right)$ nanoparticles against T.castaneum adults after different period:

\begin{tabular}{|c|c|c|c|c|c|c|}
\hline \multirow{2}{*}{ Day } & \multirow[b]{2}{*}{ LC50 } & \multicolumn{2}{|c|}{ Confidence limits } & \multirow[b]{2}{*}{ Slope \pm SE } & \multirow{2}{*}{$\begin{array}{c}\text { Chi } \\
\text { square ( } \\
\text { X2) }\end{array}$} & \multirow[b]{2}{*}{$P$ value } \\
\hline & & Lower & Upper & & & \\
\hline \multicolumn{7}{|c|}{ Aluminum oxide $\left(\mathrm{Al}_{2} \mathrm{O}_{3}\right)$ nanoparticles } \\
\hline 6 & 6.04 & 3.42 & 17.69 & $1.17 \pm 0.19$ & 4.16 & 0.24 \\
\hline 15 & 0.82 & 0.64 & 1.11 & $1.11 \pm 0.14$ & 0.54 & 0.91 \\
\hline \multicolumn{7}{|c|}{ Zinc Oxide (ZnO) nanoparticles } \\
\hline 6 & 6.23 & 3.42 & 19.61 & $1.09 \pm 0.18$ & 3.02 & 0.39 \\
\hline 15 & 0.73 & 0.57 & 0.96 & $1.12 \pm 0.14$ & 0.13 & 0.99 \\
\hline
\end{tabular}

It is known that malathion formulation comprise adjuvant materials beside the active ingredient while nanoparticles have no any additive materials where it act only by their natural properties. So, the present study suggests that the distinction of malathion effect may due to the adjuvants. However, the safety of studied nanoparticles on human and its environment make it the best for the control of stored product insects if compared with malathion which cause severe hazards on human and the environment. Also nanoparticles have longer residual activity than malathion which gradually loss its activity, in contrast the activity of nanoparticles increases with the 
increase of exposure period .in addition to nanoparticles are more persistent than malathion where the act by their natural properties.

Previous researches confirmed that metal nanoparticles are effective against plants pathogens, insects and pests. Hence, nanoparticles can be used in the preparation of new formulations like pesticides, insecticides and insect repellants (Barik et al., 2008 ; Gaibhiye et al., 2009 ; Owolade et al., 2008 and Abo Arab et al., 2014)

Amorphous nanosilica is obtained from various natural sources like the shell wall of phytoplankton, epidermis of vegetables, burnt pretreated rice hulls and straw at thermoelectric plants and volcanic soil. Amorphous nanosilica displayed promising potential as a biopesticide (Barik et al., 2008). The silica NPs were physio-sorbed by the cuticular lipids disrupting the protective barrier and thereby causing death of insects purely by physical means (Barik et al., 2008). Use of amorphous silica as a nanobiopesticide is considered safe for humans by World Health Organization (WHO). Debnath et al. (2011) observed higher insect mortality from treatment with silica nanoparticles $(15-30 \mathrm{~nm})$ than with bulk silica $(100-400 \mathrm{~nm})$. The similar efficacy of nanoparticles with different coatings (i.e., with no coating or with hydrophobic, hydrophilic, or lipophilic coatings) indicated a mechanical mode of action that could be enhanced for smaller particles. A second study, however, indicated that silica nanoparticles coated with 3mercaptopropyltriethoxysilane were more efficient than those coated with hexamethyl disilazane (Debnath et al., 2012), and in this case the effect was not related to size since the former nanoparticles $(29-37 \mathrm{~nm}$ ) were larger than the latter $(15-20 \mathrm{~nm})$.Furthermore, surface charged modified hydrophobic silica NPs $(3-5 \mathrm{~nm})$ were successfully used to control a range of agricultural insect pests and animal ecto-parasites of veterinary importance (Ulrichs et al., 2006). It was successfully applied as a thin film on seeds to decrease fungal growth and boost cereal germination (Robinson, 2010). Nano-silica may be useful against stored grain, household pests, animal parasites, fungal organisms, worms, etc.

Nano $\mathrm{Al}_{2} \mathrm{O}_{3}$ and amorphous nano $\mathrm{SiO}_{2}$ were found to be highly effective and nano $\mathrm{ZnO}$ was moderately effective against Sitophilus oryzae. But nano $\mathrm{Al}_{2} \mathrm{O}_{3}$ has deleterious effects on seeds, whereas non crystalline nano $\mathrm{SiO}_{2}$ has no such adverse effect on rice seeds. Here we present the first report showing that nanocides, especially nano $\mathrm{SiO}_{2}$ can be effectively used to control insect pests (Leiderer and Dekorsy, 2008). Yang et al., (2009) demonstrated the insecticidal activity of polyethylene glycol-coated nanoparticles loaded with garlic essential oil against adult $T$. castaneum insect found in stored products. It has been observed that the control efficacy against adult $T$. castaneum was about $80 \%$, presumably due to the slow and persistent release of the active components from the nanoparticles. Goswami et al. (2010) studied the applications of different kind of nanoparticles viz. silver nanoparticles (SNP), aluminium oxide (ANP), zinc oxide and titanium dioxide in the control of rice weevil, Sitophilus oryzae. In their study they performed bioassay, in which they prepared solid and liquid formulations of the above-mentioned nanoparticles; later, they applied these formulations on rice and kept in a plastic box with 20 adults of S. oryzae and 
observed the effects for 7 days. It was reported that hydrophilic SNP was most effective on the first day. On day 2, more than $90 \%$ mortality was obtained with SNP and ANP. After 7 days of exposure, 95 and $86 \%$ mortality were reported with hydrophilic and hydrophobic SNP and nearly $70 \%$ of the insects were killed when the rice was treated with lipophilic SNP. However, $65 \%$ mortality was observed in case of ZNP (Goswami et al.2010).

\section{REFERENCES}

Abo-Arab, R. B. ; Amal, M. Hamzah and A. S. Hashem (2014). Comparative bioactivity of Aluminum Oxide $\left(\mathrm{Al}_{2} \mathrm{O}_{3}\right)$, Titanium Dioxide $\left(\mathrm{TiO}_{2}\right)$ nanoparticles and malathion on Sitophilus oryzae L. and Sitophilus zeamais (Motsch.). Glob. J. Agric. Food Safety Sci., Vol.1 (2): pp. 2537.

Atwal, A.S., (1976). Insect pests of stored grain and other Products. In: Agricultural pests of India and South-East Asia. Kalyani Publisher, New Delhi, India, pp. 389-415.

Auffan,M.; Rose, J.; Bottero, J-Y.; Lowry, G.V.; Jolive,t. J.P. and Wiesner MR.(2009). Towards a definition of inorganic nanoparticles from an environmental, health and safety perspective.Nature Nanotechnol; 4:634-64.

Barik, T.K.; Sahu, B. and Swain, V. (2008) Nano-silica-from medicine to pest control. Parasitol Res 103:253-258.

Baruah ,S. and Dutta,J.(2009). Nanotechnology applications in pollution sensing and degradation inagriculture: a review. Environ Chem Lett; 7:161-204

Beek,W.J.E.;Wienk,M.M.;Kemerink,M.;Yang,X. and Janssen,R.A.J.(2005). Journal of Phys. Chem. B,109,9505-16.

Dars, F.; Rustamani, M.A.; Khuro, R.D. and Baloch, H.B. (2001). Effect of wheat grain moisture on infestation of red flour beetle, Tribolium castaneum (Herbst.). Pakistan J. Zool., 33: 189-200.

Debnath, N.; Das, S.; Seth, D.; Chandra, R.; Bhattacharya, S.C. and Goswami, A.(2011). Entomotoxic effect of silica nanoparticles against Sitophilus oryzae (L.). J.Pest Sci;84:99-105.

Debnath, N.; Mitra, S.; Das, S. and Goswami, A.(2012). Synthesis of surface functionalized silica nanoparticles and their use as entomotoxic nanocides. Powder Technol 2012; 221:252-6. http://dx.doi.org/10.1016/j.powtec.01.009.

Ezz,E.(1976).Studies of damage in some stored grains due to infestation with certain insects . PhD .Thesis, Fac. Agric. Cairo Univ.

Gajbhiye, M;Kesharwani ,J. ;Ingle, A.; Gade, A. and Rai, M. (2009) Fungus mediated synthesis of silver nanoparticles and its activity against pathogenic fungi in combination of fluconazole. Nanomedicine 5 (4):282-286.

Goswami, A.; Roy, I; Sengupta, S. and Debnath, N. (2010). Novel applications of solid and liquid formulations of nanoparticles against insect pests and pathogens. Thin Solid Films 519:1252-1257. 
Hamed, M. and Khsttsk, S.U., (1985). Red flour beetle: development and losses in various stored food stuffs. Sarhad J. Agric., 1: 97-101.

Hochepied, J.F. ; Ilioukhina, O. and Berger, M.H. (2003).Mater. Lett. 57 2817.

Khattak, S.U.K.; Khatoon, R. and Wahid, M., (1999). Insect attack and nutritional losses in stored dried fruits. The Nucleus, 6: $113-116$.

Kuzma J. (2007).Moving forward responsibly: Oversight for the nanotechnology-biology interface. J Nanopart Res;9:165-82.

Leiderer, P. and Dekorsy, T. (2008). Interactions of nanoparticles and surfaces Tag der mÄundlichenPrÄufung: 25. April. URL: http://www.ub.unikonstanz.de/kops/ volltexte/2008/5387/; URN: http://nbn-resolving.de/urn: nbn: de:bsz:352-opus-53877.

LI, L. and Arbogast, R.T. (1991). The effect of grain breakage on fecundity, development, survival and population increase in maize of Tribolium castaneum (Herbst) (Coleoptera: Tenebrionidae). J. Stored Prod. Res., 27: 87-94.

Navrotsky, A.(2000). Technology and applications Nanomaterials in the environment, agriculture, and technology (NEAT). J Nanopart Res;2:321-3.

Niemeyer, C.M. and Doz, P.(2001). Nanoparticles, proteins, and nucleic acids: biotechnology meets materials science. Angewandte Chemie Int Ed; 40:4128-58.

Oskam, G.(2006). Metal oxide nanoparticles: synthesis, characterization and application. J SolGel Sci Technol;37:161-4.

Owolade OF, Ogunleti DO, Adenekan MO (2008) Titanium dioxide affects disease development and yield of edible cowpea. Elect $\mathrm{J}$ Environ Agri Food Chem 7(50):2942-2947.

Puoci, F.; Lemma, F.; Spizzirri, U.G.; Cirillo,G. ;Curcio, M, and Picci N.(2008). Polymer in agriculture: a review. Am J Agri Biol Sci; 3:299-314.

Robinson, D.K.R. and Salejova-Zadrazilova, G. Observatory (2010) Nanotechnologies for nutrient and biocide delivery in agricultural production. Working Paper Version.

Ruihong, Z. ; G. Fen and Z. Hu Yongqui. Huanqi, (2006). Micropor.Mesopor.Mater. 93 , 212.

SAS.(2008).SAS/STAT 9.2 Version Users Guide. AS Institute Inc., Gary , North Carolina,USA.

Seow, Z . L . S . ; Wong , A . S . W. ; Thavasi , V . ; Jose , P . ; Ramakrishna, S . and Ho,G.W.(2009).Nanotechnology,20,045604(6pp).

Ulrichs, C.; Krause, F.; Rocksch, T.; Goswami, A. and Mewis, I. (2006). Electrostatic application of inert silica dust based insecticides onto plant surfaces. Commun Agric Appl Biol Sci;71:171-8.

Yang, F.L.; Li, X.G.; Zhu, F and Lei, C.L. (2009). Structural characterization of nanoparticles loaded with garlic essential oil and their insecticidal activity against Tribolium castaneum (Herbst) (Coleoptera:Tenebrionidae). J Agric Food Chem 57(21):1015610162. 


\section{أستخدام دقائق اكاسيد الالمونيوم والزنك كطريقه جديده فى مكافحة خنفسـاء الدقيق

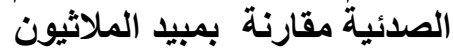

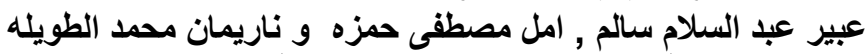

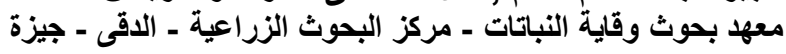

تعتبر خنفساء الدقيق الصدئيه واحده من أوسع الحشر ات انتشـار ا فى العـالم وافهـ

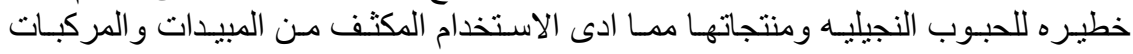

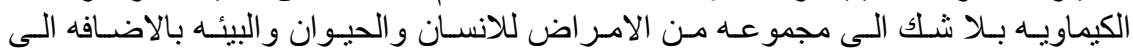

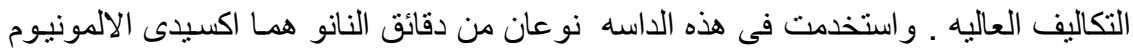

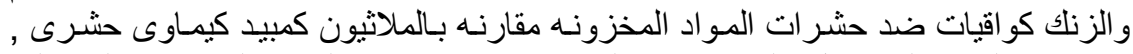

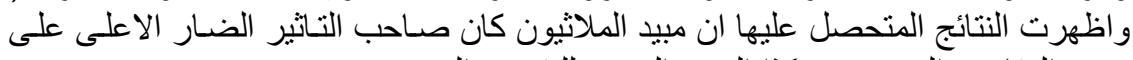

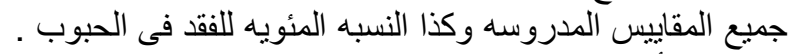

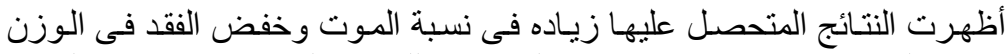

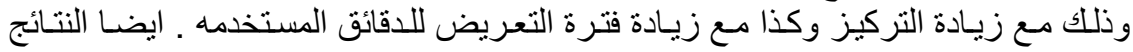

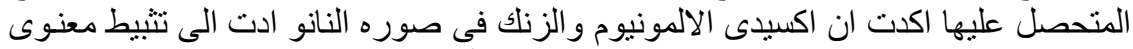

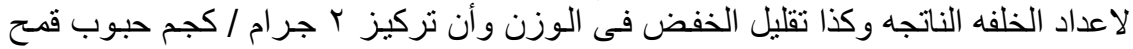

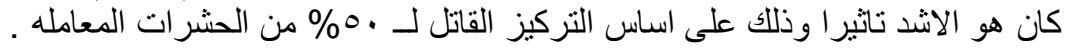

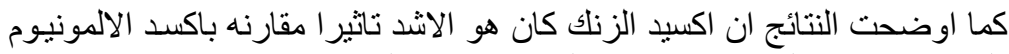

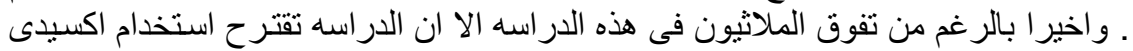

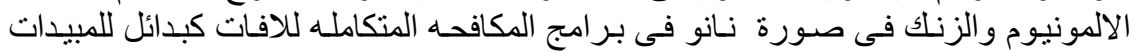
الكيماويه حيث تعتبر امنه للانسان اذا ما فورنت فئت بالمبيدات المصافه المنكانه 